\title{
Association of Lipid Profile Biomarkers with Breast Cancer by Molecular Subtype: analysis of the Mechanisms for Established and Novel Risk Factors for Breast Cancer in Women of African Descent (MEND) study
}

Tomi Akinyemiju ( $\nabla$ tomi.akinyemiju@duke.edu )

Duke University School of Medicine https://orcid.org/0000-0002-1412-3234

Anjali Gupta

Duke University

\section{Veeral Saraiya}

University of North Carolina at Chapel Hill Gillings School of Global Public Health

April Deveaux

Duke University

Taofik Oyekunle

Duke University

Omolola Salako

Lagos University Teaching Hospital

Adetola Daramola

Lagos University Teaching Hospital

Allison Hall

Duke University

Olusegun Alatise

Obafemi Awolowo University Teaching Hospital Complex

Gabriel Ogun

University College Hospital Ibadan

Adewale Adeniyi

Federal Medical Centre Abeokuta

Akinlolu Ojo

University of Arizona Medical Center - University Campus: Banner University Medical Center Tuscon

Omobolaji Ayandipo

Our Lady of Apostle Catholic Hospital Ibadan

Thomas Olajide

Lagos University Teaching Hospital 


\section{Olalekan Olasehinde}

Obafemi Awolowo University Teaching Hospital Complex

Olukayode Arowolo

Obafemi Awolowo University Teaching Hospital Complex

\section{Adewale Adisa}

Obafemi Awolowo University Teaching Hospital Complex

\section{Oludolapo Afuwape}

University College Hospital Ibadan

\section{Aralola Olusanya}

University College Hospital Ibadan

\section{Aderemi Adegoke}

Our Lady of Apostle Catholic Hospital Ibadan

\section{Trygve 0 Tollefsbol}

University of Alabama at Birmingham

\section{Donna Arnett}

University of Kentucky

\section{Michael J Muehlbauer \\ Duke University \\ Christopher B Newgard \\ Duke University}

\section{Research Article}

Keywords: cholesterol, breast cancer, Nigeria, molecular subtype, lipid

Posted Date: March 10th, 2021

DOl: https://doi.org/10.21203/rs.3.rs-271970/v1

License: (c) (1) This work is licensed under a Creative Commons Attribution 4.0 International License. Read Full License 


\section{Abstract}

Purpose: There is conflicting evidence on the role of lipid biomarkers in breast cancer (BC), and no study to our knowledge has examined this association among African women.

Methods: We estimated odds ratios (ORs) and 95\% confidence intervals (95\% Cl) for the association of lipid biomarkers - total cholesterol, high-density lipoprotein (HDL), low-density lipoprotein (LDL), and triglycerides - with odds of BC overall and by subtype (Luminal A, Luminal B, HER2-enriched and triplenegative or TNBC) for 296 newly diagnosed BC cases and 116 healthy controls in Nigeria.

Results: Cases were slightly older than controls (48.5 vs. 46.0) and had a lower BMI (25.4 vs. 26.5). Each unit SD increase in triglycerides was associated with $39 \%$ increased odds of BC in fully adjusted models (aOR: $1.39 ; 95 \% \mathrm{Cl}: 1.03,1.86)$. However, there were no significant associations of total cholesterol, LDL and HDL with odds of breast cancer in fully adjusted models. In analysis of molecular subtypes, each unit SD increase in LDL was associated with $64 \%$ increased odds of Luminal B BC (aOR 1.64; $95 \% \mathrm{Cl}$ : $1.06,2.55)$. Each unit SD decrease in HDL was associated with $49 \%$ increased odds of TNBC (aOR: 1.49 , $95 \% \mathrm{Cl}: 0.94,2.34)$, and clinically low HDL was associated with 2.7 times increased odds of TNBC (aOR $2.67 ; 95 \% \mathrm{Cl}: 1.10,6.49)$.

Conclusions: Low HDL and high LDL appear to significantly increase the odds of TN and Luminal B BC, among African women. Future prospective studies can characterize this association and inform clinical approaches targeting HDL as a BC prevention strategy.

\section{Introduction}

Breast cancer (BC) in Nigeria, like in other West African countries and among Blacks in the United States, is characterized by disproportionately high rates of the triple-negative $(T N)$ molecular subtype $[1,2]$. TNBCs are aggressive cancers, described by estrogen (ER), progesterone (PR), and human epidermal growth factor-2 (HER2) receptor negativity and associated with poor clinical outcomes [3,4]. Africa suffers from the highest age-standardized BC mortality rate globally [5], and the past few decades have observed increasing $\mathrm{BC}$ incidence on the African continent [6]. An understanding of the risk factors contributing to the higher prevalence of TNBCs among women of African descent is crucial to the development of preventive interventions that may reduce the $\mathrm{BC}$ burden within this population. In addition to increasing $\mathrm{BC}$ incidence, the African continent has also experienced significantly increasing rates of obesity, diabetes, and dyslipidemia (abnormally elevated blood cholesterol or lipid levels), so called "diseases of affluence" due to globalization and the epidemiologic transition [7,8]. Prior studies have documented a positive association between measures of excess adiposity and $B C$ incidence $[9,10]$, but none to our knowledge has examined specific biomarkers associated with dyslipidemia with BC risk by molecular subtype on the African continent.

Prior studies in the US, Europe and parts of Asia evaluating the relationship between serum lipids and risk of $\mathrm{BC}$ have been inconclusive, and several review papers have summarized published results on this 
topic. A recent systematic review of prospective studies reported an inverse association between biomarkers of total cholesterol and high-density lipoprotein (HDL) cholesterol and risk of breast cancer, but no significant associations with low-density lipoprotein (LDL) cholesterol [11]. This study noted significant heterogeneity among included studies for total cholesterol based on geographical location. The inverse association for HDL cholesterol was replicated in a separate systematic review which also reported a positive association for LDL cholesterol [12]. A third meta-analysis found that higher triglyceride levels, but not total cholesterol, HDL cholesterol or LDL cholesterol levels was inversely associated with BC risk [13]. It is worth noting that the majority of studies on this topic have been conducted among White populations in the United States and Europe. Studies among African American populations are limited and conflicting. While one study among African Americans in the United States found a statistically significant reduction in $\mathrm{BC}$ risk with high levels of total cholesterol and a significant increase in risk associated with low HDL cholesterol [14]; another study reported no significant association with total cholesterol [15]. Research on this topic deserves further study to more clearly elucidate the association between lipid biomarkers and BC risk. To our knowledge, studies on this topic have not been conducted in Nigeria or West Africa.

Importantly, few epidemiological studies have examined the association between lipids and BC molecular subtype. One study in Korea noted that low HDL cholesterol and high levels of triglycerides were associated with an increased risk of developing hormone receptor negative tumors [16]. Another study in Spain found that the risk of postmenopausal Luminal A BC significantly increased with higher circulating levels of triglycerides [17]. However, no study to our knowledge has examined this association among African women or in African American women, despite the higher risk of TNBC in these populations. To our knowledge, ours is the first study to evaluate the association between total cholesterol, LDL cholesterol, HDL cholesterol, and triglycerides with BC molecular subtypes among Nigerian women. Blood lipids are easily measurable markers that are routinely assessed in clinical practice. Thus, further insight on this relationship by molecular subtype may enable the development of preventative strategies that are well-suited to the Nigerian and African context.

\section{Materials And Methods}

\section{Study design}

The Mechanisms for Established and Novel Risk Factors for Breast Cancer in Women of African Descent (MEND) study has been previously described in detail [18]. Briefly, MEND enrolled newly diagnosed BC patients from four hospitals in southwestern Nigeria. At each hospital site, a trained nurse explained the study requirements to $\mathrm{BC}$ patients during their clinical visits. Interested participants were evaluated for eligibility. Reasons for exclusion included an inability to communicate in English to complete the required baseline survey, prior diagnosis and/or treatment for cancer, and other medical conditions that may have interfered with participation in the study. All study participants gave written and verbal informed consent, and then completed a questionnaire that covered information on sociodemographic characteristics, reproductive history, and past personal and family history of cancer. Anthropomorphic measurements 
were taken, and blood samples and tumor biopsy samples were collected for all participants prior to receipt of any surgery, chemotherapy, or radiation treatment. After collection and processing, tissue and blood samples were stored in $-80^{\circ} \mathrm{C}$ freezers until shipment to the United States for assays and further analysis. For their participation in this study, participants received an N500 telephone recharge card (valued at US \$1.50) in addition to the supplies necessary for their biopsy. Healthy controls were selected from a cohort of 4,000 healthy, community-based women recruited as part of the Human Heredity and Health (H3) Africa Chronic Kidney Disease (CKD) Case-Control study [19]. The CKD study recruited from Nigeria and Ghana between 2015 and 2017, overlapping with case recruitment. The present analysis was restricted to controls recruited from Nigeria; recruitment occurred in the South-Western region of the country, also overlapping with case recruitment region. Extensive socio-demographic, clinical, family history and behavioral risk factor data was collected, and blood samples were collected and processed at clinical labs following a standardized protocol. Serum samples for cases and controls were assayed for lipid biomarkers at the Duke Molecular Pathology Institute at the same time, and the laboratory technician was blinded to case status. These procedures were approved by the Institutional Review Boards at Duke University and the participating hospitals.

\section{Breast cancer cases and subtyping}

BC diagnosis was ascertained either through pathology reports of clinical biopsy samples evaluated by a trained pathologist from the diagnosing hospital in Nigeria, or from samples that were shipped to the US for review by a trained US pathologist. If either indicated a cancer diagnosis, the sample was considered a confirmed case. Confirmed samples underwent immunohistochemistry in Nigeria as part of regular standard of care procedures, or at the Duke University BioRepository and Precision Pathology Center. If results from both were available, US typing was used as it constituted most of the available immunohistochemistry information on cases. Estrogen receptor (ER) and progesterone receptor (PR) status was scored using the Allred method $[20,21]$. The intensity of staining was categorized as 0 (none), 1 (mild), 2 (moderate), or 3 (strong), and the proportion of nuclear positivity was scored into $0(0 \%), 1$ (<1\%), 2 (1-10\%), $3(11-33 \%), 4(33-66 \%)$ or $5(67-100 \%)$. The numbers from these two scores were summed to positive (3-8) or negative (0-2). HER2 status was categorized as negative (scores = 0-1), equivocal (score $=2$ ), or positive (score $=3$ ) [22]. In the determination of subtype, equivocal was classified as negative. Based into these categorizations, cancer subtype was determined: Luminal A (ER+ and/or PR+ / HER2-), Luminal B (ER+ and/or PR+ / HER2+), TN (ER-/PR-/HER2-), or HER2 (ER-/PR-/HER2+). In all, there were 124 cases with available data on ER/PR/HER2 status for classification into a molecular subtype.

\section{Measures}

Measurements of total cholesterol, HDL, LDL, and triglycerides for cases and controls were performed using a Beckman DxC 600 clinical analyzer with assays that utilized standard reagents also from Beckman (Brea, CA). Following the joint harmonized criteria for metabolic syndrome and guidelines set by the National Cholesterol Education Program, high total cholesterol was defined as $>200 \mathrm{mg} / \mathrm{dL}$ [23]; 
low HDL was defined as $<50 \mathrm{mg} / \mathrm{dL}$ [24]; high LDL was defined as $>100 \mathrm{mg} / \mathrm{dL}$ [23]; and high triglycerides was defined as $>150 \mathrm{mg} / \mathrm{dL}$ [24]. In addition, lipid measures were specified as standard deviation (SD) change by subtracting the sample mean from individual measurements and dividing by the sample standard deviation. Other covariates included in analysis were staff assessed height, weight, blood pressure; participants self-reported reproductive and clinical history, including age at menarche, number of pregnancies, number of births, and menopausal status. Participants who self-reported a history of cancer and those missing this information were excluded from the present analysis, in addition to participants who were missing information on their menopausal status. Missing values for variables with $<10 \%$ missing for both cases and controls were replaced with the median (for continuous variables) or modal (for categorical variables) value of their respective group. For variables with more than $>10 \%$ missing, a separate "missing" category was included (age at menarche).

\section{Analytical approach}

The sample was characterized via descriptive statistics, and results were reported as frequencies and proportions for categorical variables and medians (first quartile, third quartile) for continuous variables. Differences in associations by case/control status were tested using chi-square $\left(\chi^{2}\right)$ tests or Fisher exact tests for categorical variables and Kruskal-Wallis nonparametric tests for continuous variables. We estimated the association between each lipid biomarker (total cholesterol, HDL, LDL, and triglycerides) and odds of BC using logistic regression models. Each measure was analyzed separately in the following three models: unadjusted, adjusted for age only, and adjusted for age, body mass index (BMI), age at menarche, number of pregnancies, number of births, hypertension at enrollment, and menopausal status. In a final model, we mutually adjusted for all lipid measures in addition to all previous covariates. In each model, we specified each lipid biomarker as a categorical variable (high vs. low for total cholesterol, LDL, and triglycerides; and low vs. high for HDL), and also evaluated continuous measures of total cholesterol, HDL, LDL, and triglycerides based on one-unit standard deviation increase (for total cholesterol, LDL, and triglycerides) or decrease (for $\mathrm{HDL}$ ). We further analyzed the subset of cases with cancer subtyping data available via multinomial logistic regression models. Control status was specified as the outcome reference group, and the fully adjusted model was repeated here to predict the odds of having Luminal $A$, Luminal B, TN, HER2 cancer subtypes. SAS v9.4 (SAS Institute, Cary, NC) was used for all analyses and significance was set at $\mathrm{a}=0.05$.

\section{Results}

The present analysis includes 296 BC cases and 116 healthy controls (Figure 1). Cases were slightly older than controls-the median age at diagnosis for cases was 48.5 years, and the median age at enrollment for controls was 46 years $(p=0.0328$; Table 1$)$. There were no significant differences in reproductive characteristics among cases vs. controls; number of pregnancies $(p=0.7457)$, number of births $(p=$ $0.7457)$, or menopausal status ( $p=0.8799)$ among cases and controls. However, cases were more likely than controls to have high diastolic blood pressure $(p=0.0056)$, while controls were more likely to have higher BMI $(p=0.0451)$. Across total cholesterol quartiles (Table 2$)$, those in the highest cholesterol group 
were older $(p=0.0003)$, and more likely to be a higher weight $(p=0.0593)$, have a higher blood pressure (systolic: $p=0.0067$; diastolic: $p=0.0202)$ and be post-menopausal $(p=0.0003)$. A higher proportion of controls relative to cases were within the lowest total cholesterol quartiles among participants who were 60 years or older and among those who were post-menopausal (Figure 2).

In fully adjusted multivariable logistic regression models (Table 3), one-unit SD increase in triglycerides was associated with $39 \%$ increased odds of BC (aOR: 1.39; $95 \% \mathrm{Cl}: 1.03,1.86)$. High total cholesterol (aOR: $1.24 ; 95 \% \mathrm{Cl}: 0.94,1.65)$ and LDL (aOR: $1.29 ; 95 \% \mathrm{Cl}: 0.97,1.72)$ were associated with increased odds of BC, while low HDL (aOR: $0.89 ; 95 \%$ Cl: $0.69,1.14$ ) was associated with reduced odds of BC but none of these estimates were statistically significant. In mutually adjusted models including all four lipid profile measures, each SD increase in triglycerides remained significantly associated with odds of BC (aOR 1.47; 95\% $\mathrm{Cl} 1.06,2.03$ ). No significant associations were noted for total cholesterol, HDL cholesterol, and LDL cholesterol in mutually adjusted models. Similar results were observed when examining categorical cut-points. In multinomial logistic regression models predicting the odds of each molecular subtype relative to controls (Table 4; Figure 3), clinically low HDL was associated with 2.7 times the odds of TNBC (aOR: 2.67; 95\% Cl: 1.10, 6.49). Additionally, each unit SD decrease in HDL was associated with $49 \%$ increased odds of TNBC (aOR 1.49; $95 \%$ Cl: $0.94,2.34$ ), and each unit SD increase in LDL was associated with $64 \%$ increased odds of Luminal B BC (aOR: 1.64; $95 \% \mathrm{Cl}: 1.06,2.55)$.

\section{Discussion}

For the first time, we describe the results of a case-control analysis of lipid biomarkers (total cholesterol, HDL cholesterol, LDL cholesterol, and triglycerides) and odds of BC and molecular subtypes among African women. Among cases and controls, those who were older, had high BMl and high blood pressure at enrollment were more likely to have high cholesterol. High triglycerides was the only lipid biomarker significantly associated with odds of BC in fully adjusted models. However, for molecular subtypes, low HDL and high LDL were significantly associated with odds of TNBC and Luminal B subtypes, respectively. None of the other lipid biomarkers were significantly associated with $B C$ in this cohort.

Several past studies among populations from the United States, Europe, and Asia have evaluated the association between lipid biomarkers and BC risk, however results have been inconsistent. For total cholesterol, one study in Korea noted a positive association with BC risk [25], but others in the United States and Europe, like ours, have found no association [15,26], and one study additionally observed an inverse association [27]. In the context of LDL, a case-control study among African American women in the United States found a 59\% reduction in risk among those who had clinically high levels of LDL cholesterol [14]. Other studies in the United States, Asia, and Europe, like ours, have also found no association [28,13], although one Mendelian randomization study among those of European descent documented a positive association [29]. We did not observe a significant association between HDL cholesterol and odds of BC. One study in Europe found an inverse association between HDL cholesterol 
and $\mathrm{BC}$ risk [27], while a Mendelian randomization analysis in Europe found that an increase in genetically-predicted HDL was associated with increased BC risk [30]. However, others in the United States and Europe have failed to find an association with HDL [28,31]. Regarding triglycerides, one study using the Swedish AMORIS database noted a weak protective association with risk of BC [32], while others still have reported no association $[27,33]$. On the contrary, two small case-control studies in India and the United States, like ours, found a positive association between triglycerides and $\mathrm{BC}[34,35]$. Ultimately, there is inconclusive evidence regarding the role of lipid biomarkers in BC risk, suggesting that additional studies on this topic are still warranted, and importantly, studies from diverse populations will be needed to determine if region-specific associations may explain the disparate findings.

Our analysis of Nigerian women on the association between lipid measures and BC subtypes revealed that low HDL cholesterol level is associated with increased odds of TNBC and that high LDL is associated with increased odds of Luminal B BC. Our HDL result is consistent with findings from a study from Korea reporting that low HDL cholesterol and high triglycerides were associated with an increased risk of developing hormone receptor negative tumors among premenopausal women [16]. Further, dyslipidemia, investigated as part of metabolic syndrome, was associated with TNBC, and specifically, low HDL was associated with TNBC among patients from the United States [36]. However, our subtype findings are inconsistent with a separate study in Spain that found that $B C$ risk increased with increasing triglyceride levels among postmenopausal Luminal A BC [37]. Due to limitations in our sample size for the molecular subtype analysis, we were unable to stratify our sample by menopausal status; given that the majority of BC in Nigeria is pre-menopausal, future studies with larger sample sizes will be needed to examine these associations. Given that epidemiologic studies evaluating the association of lipid biomarkers and $\mathrm{BC}$ subtypes are very limited, our findings provide important initial evidence upon which future studies can expand.

The biological mechanisms underlying the association between lipids and $\mathrm{BC}$ remains unclear and is an active area of research. Studies have suggested that elevated serum cholesterol levels may advance tumor progression [38], and a recent review of laboratory studies suggests that cholesterol is capable of regulating proliferation, migration, and signaling pathways in $\mathrm{BC}$ [39]. Research on mechanisms underlying risk by molecular BC subtype is limited, however, as suggested by Llanos et al. [14], it is possible that $\mathrm{HDL}$ influences overall $\mathrm{BC}$ risk by moderating biologically active estradiol [40], a risk factor for BC among postmenopausal women [41]. Low HDL cholesterol may reflect an unfavorable hormonal profile, and the conversion of androgens to estrogens within adipose tissues may represent a causal mechanism for the inverse association between HDL and BC risk [40]. Fernandez and Murillo demonstrated that HDL is inversely correlated with waist circumference and higher BMI [42], providing support for the mediating role of adiposity. It is also possible that HDL plays a key role in reverse cholesterol transport that may contribute to the blocking of tumor progression and ultimately $\mathrm{BC}$ incidence. Although reverse cholesterol transport may be its primary role, HDL has also been shown to possess antimicrobial, antioxidant, antiglycation, anti-inflammatory, antiatherogenic, and immunosuppressive properties [43-45]. The numerous functions of HDL provide a plethora of opportunities for novel research, but also make pinpointing the exact mechanism by which it may confer 
protection against $\mathrm{BC}$ difficult. Some of the conflicting results in the epidemiology of HDL and BC risk may be explained, in part, by the observation that the environment in which HDL exists in the body may influence its effect on BC cells. Pan and colleagues used in vivo and in vitro models of $\mathrm{BC}$ and observed that oxidized HDL and HDL derived from diabetic patients were associated with the promotion of metastasis and invasion to surrounding tissues [46-48]. Still, these explanations are not specific to TNBC and further studies are needed to fully characterize these mechanisms by BC subtype.

Understanding the mechanism by which HDL has shown an inverse association with TNBC is further complicated by challenges related to sample size as TNBC typically accounts for an estimated $15-20 \%$ of all BCs. Further, although an estimated $80 \%$ of TNBC are classified as the basal BC intrinsic subtype [49], new research suggests that TNBC may actually be quite heterogenous with respect to cellular and molecular features [50]. African American women tend to demonstrate patterns of TNBC occurrence that map more closely with women from western and sub-Saharan Africa than they do with women from east Africa, implicating a role of genetic factors [51,52]. That clinically low HDL was associated with TNBC provides a possibility of a therapeutic target for the BC subtype that is the most aggressive, has a poor prognosis, and by definition, cannot be targeted with pharmaceutical therapy designed for ER+ cancers. Still as we point out, the mechanisms underlying the inverse association between HDL and TNBC risk requires vigorous investigations, perhaps pooled analyses across existing studies may provide additional insight.

There are several strengths and limitations of this study that may impact the interpretation of these results. Many covariates were self-reported by participants, potentially introducing recall bias into our analysis. However, our main exposures of interest, namely total cholesterol, HDL, LDL, and triglycerides were assayed for cases and controls at the same time following the same standard assay protocol, thus minimizing batch effects. Additionally, due to the case-control study design, we are unable to rule out the possibility of reverse causality. It is possible that lipid levels may be influenced by the presence of BC, producing the observed association. Strengths of our study include the use of histologically confirmed cancer cases and pathologically verified molecular subtypes assessed by a single pathologist, the availability of data on critical reproductive history and clinical characteristics for covariate adjustment, and the unique study population of Nigerian women-adding to the diversity of study populations for this topic. Although our sample size is modest compared with other large cohorts, we emphasize that our study is the first to characterize the association between lipid profile measures and BC risk in Nigeria, and one of very few studies worldwide to evaluate the association between lipid profile measures and $B C$ risk by subtype. We lay important groundwork for future large prospective studies among African women.

In conclusion, we report a positive association between triglycerides and odds of $\mathrm{BC}$, and between low HDL with TNBC, and high LDL with Luminal B BC. Lipids are easily measured in clinical settings, making this an attractive target for cancer prevention strategies that may reduce the risk of BC.

\section{Abbreviations}


BMI

body mass index

BC

breast cancer

CKD

Chronic Kidney Disease

ER

estrogen receptor

HDL

high-density lipoprotein

HER2

human epidermal growth factor-2

H3

Human Heredity and Health

LDL

low-density lipoprotein

MEND

Mechanisms for Established and Novel Risk Factors for Breast Cancer in Women of African Descent PR

progesterone receptor

$\mathrm{TN}$

triple-negative

\section{Declarations}

Funding Source: This research was funded by National Institutes of Health, National Cancer Institute, Fogarty International Center, grant number K01TW010271 (T.A.) and National Institutes of Health, grant number NIH 1P30DK124723-01.

Competing Interests: The authors have no competing interests to declare.

Ethics Approval: This study was approved by Duke University and the participating hospitals' Institutional Review Boards (Pro00102004). The study was performed in accordance with the ethical standards as laid down in the 1964 Declaration of Helsinki and its later amendments or comparable ethical standards.

Consent to Participate: All participants included provided informed consent.

Data Availability Statement: The data that support the findings of the study are available from the corresponding author upon reasonable request.

\section{Acknowledgements}


We acknowledge the role of the H3Africa Consortium in making this research possible though the sharing of data. The National Institutes of Health (USA) and Wellcome Trust (UK) have provided the core funding for the H3Africa Consortium. We thank the many MEND investigators who contributed substantially to the inception and design of the study, and the patients and families who participated in the MEND study for their vital contribution in advancing the science of cancer in Nigeria and globally. We acknowledge the important contribution of the MEND research nurses: Cordelia Ibeneme, Peju Olabanji, Rebecca Israel, Esther Akinwale, Deborah Awodeyi, and Shukurat Oduola.

\section{Compliance with Ethical Standards:}

Funding: This research was funded by National Institutes of Health, National Cancer Institute, Fogarty International Center, grant number K01TW010271 (T.A.) and National Institutes of Health, grant number $\mathrm{NIH}$ 1P30DK124723-01. The views expressed in this paper do not represent the views of the National Institutes of Health, H3Africa Consortium or their funders.

Conflict of Interest: The authors have no conflicts of interest to declare.

Ethical Approval: All procedures performed in studies involving human participants were in accordance with the ethical standards of the institutional and/or national research committee and with the 1964 Helsinki declaration and its later amendments or comparable ethical standards. This article does not contain any studies with animals performed by any of the authors.

Informed consent: Informed consent was obtained from all individual participants included in the study.

\section{References}

1. Dietze EC, Sistrunk C, Miranda-Carboni G, O'Regan R, Seewaldt VL (2015) Triple-negative breast cancer in African-American women: disparities versus biology. Nature reviews Cancer 15(4):248254. doi:10.1038/nrc3896

2. Newman LA, Jenkins B, Chen Y, Oppong JK, Adjei E, Jibril AS, Hoda S, Cheng E, Chitale D, Bensenhaver JM, Awuah B, Bekele M, Abebe E, Kyei I, Aitpillah F, Adinku M, Nathanson SD, Jackson L, Jiagge E, Merajver S, Petersen LF, Proctor E, Gyan KK, Martini R, Kittles R, Davis MB (2019) Hereditary Susceptibility for Triple Negative Breast Cancer Associated With Western Sub-Saharan African Ancestry: Results From an International Surgical Breast Cancer Collaborative. Annals of surgery 270(3):484-492. doi:10.1097/sla.0000000000003459

3. Wright N, Rida P, Rakha E, Agboola A, Aneja R (2018) Panoptic Overview of Triple-Negative Breast Cancer in Nigeria: Current Challenges and Promising Global Initiatives. Journal of global oncology 4:1-20. doi:10.1200/jgo.17.00116 
4. Kumar P, Aggarwal R (2016) An overview of triple-negative breast cancer. Archives of gynecology obstetrics 293(2):247-269. doi:10.1007/s00404-015-3859-y

5. Azubuike SO, Muirhead C, Hayes L, McNally R (2018) Rising global burden of breast cancer: the case of sub-Saharan Africa (with emphasis on Nigeria) and implications for regional development: a review. World J Surg Oncol 16(1):63. doi:10.1186/s12957-018-1345-2

6. Adeloye D, Sowunmi OY, Jacobs W, David RA, Adeosun AA, Amuta AO, Misra S, Gadanya M, Auta A, Harhay MO, Chan KY (2018) Estimating the incidence of breast cancer in Africa: a systematic review and meta-analysis. Journal of global health 8(1):010419. doi:10.7189/jogh.08.010419

7. McKeown RE (2009) The Epidemiologic Transition: Changing Patterns of Mortality and Population Dynamics. Am J Lifestyle Med 3(1 Suppl):19s-26s. doi:10.1177/1559827609335350

8. $10.1001 /$ jamaoncol.2016.5688

9. Okobia MN, Bunker CH, Zmuda JM, Osime U, Ezeome ER, Anyanwu SN, Uche EE, Ojukwu J, Kuller LH (2006) Anthropometry and breast cancer risk in Nigerian women. The breast journal 12(5):462-466. doi:10.1111/j.1075-122X.2006.00304.x

10. Ogundiran TO, Huo D, Adenipekun A, Campbell O, Oyesegun R, Akang E, Adebamowo C, Olopade OI (2012) Body fat distribution and breast cancer risk: findings from the Nigerian breast cancer study. Cancer causes control: CCC 23(4):565-574. doi:10.1007/s10552-012-9916-y

11. Touvier M, Fassier P, His M, Norat T, Chan DS, Blacher J, Hercberg S, Galan P, Druesne-Pecollo N, Latino-Martel P (2015) Cholesterol and breast cancer risk: a systematic review and meta-analysis of prospective studies. Br J Nutr 114(3):347-357. doi:10.1017/s000711451500183x

12. Cedó L, Reddy ST, Mato E, Blanco-Vaca F, Escolà-Gil JC (2019) HDL and LDL: Potential New Players in Breast Cancer Development. Journal of clinical medicine 8 (6). doi:10.3390/jcm8060853

13. Ni H, Liu H, Gao R (2015) Serum Lipids and Breast Cancer Risk: A Meta-Analysis of Prospective Cohort Studies. PloS one 10(11):e0142669. doi:10.1371/journal.pone.0142669

14. Llanos AA, Makambi KH, Tucker CA, Wallington SF, Shields PG, Adams-Campbell LL (2012) Cholesterol, lipoproteins, and breast cancer risk in African American women. Ethn Dis 22(3):281-287

15. Bosco JL, Palmer JR, Boggs DA, Hatch EE, Rosenberg L (2012) Cardiometabolic factors and breast cancer risk in U.S. black women. Breast cancer research treatment 134(3):1247-1256. doi:10.1007/s10549-012-2131-4

16. Kim Y, Park SK, Han W, Kim DH, Hong YC, Ha EH, Ahn SH, Noh DY, Kang D, Yoo KY (2009) Serum high-density lipoprotein cholesterol and breast cancer risk by menopausal status, body mass index, and hormonal receptor in Korea. Cancer epidemiology, biomarkers \& prevention: a publication of the American Association for Cancer Research, cosponsored by the American Society of Preventive Oncology 18 (2):508-515. doi:10.1158/1055-9965.Epi-08-0133

17. Gago-Dominguez M, Calaza M, Muñoz-Garzon V, Martinez ME, Castelao JE (2017) Abstract 2269: Circulating lipids and breast cancer subtypes in a Spanish population. 77 (13 Supplement):22692269. doi:10.1158/1538-7445.AM2017-2269 \%J Cancer Research 
18. Akinyemiju T, Salako O, Daramola A, Alatise O, Adeniyi A, Ogun G, Ayandipo O, Olajide T, Olasehinde O, Arowolo O, Adisa A, Afuwape O, Olusanya A, Adegoke A, Ojo A, Tollefsbol T, Arnett D (2019) Collaborative Molecular Epidemiology Study of Metabolic Dysregulation, DNA Methylation, and Breast Cancer Risk Among Nigerian Women: MEND Study Objectives and Design. Journal of global oncology 5:1-9. doi:10.1200/jgo.18.00226

19. Osafo C, Raji YR, Burke D, Tayo BO, Tiffin N, Moxey-Mims MM, Rasooly RS, Kimmel PL, Ojo A, Adu D, Parekh RS (2015) Human Heredity and Health (H3) in Africa Kidney Disease Research Network: A Focus on Methods in Sub-Saharan Africa. Clinical journal of the American Society of Nephrology: CJASN 10(12):2279-2287. doi:10.2215/cjn.11951214

20. Mukherjee T (2016) Interpretation of ER and Her2neu hormonal receptor in breast cancer. Medical journal. Armed Forces India 72(1):99. doi:10.1016/j.mjafi.2015.11.007

21. Hammond ME, Hayes DF, Dowsett M, Allred DC, Hagerty KL, Badve S, Fitzgibbons PL, Francis G, Goldstein NS, Hayes M, Hicks DG, Lester S, Love R, Mangu PB, McShane L, Miller K, Osborne CK, Paik S, Perlmutter J, Rhodes A, Sasano H, Schwartz JN, Sweep FC, Taube S, Torlakovic EE, Valenstein P, Viale G, Visscher D, Wheeler T, Williams RB, Wittliff JL, Wolff AC (2010) American Society of Clinical Oncology/College of American Pathologists guideline recommendations for immunohistochemical testing of estrogen and progesterone receptors in breast cancer (unabridged version). Arch Pathol Lab Med 134(7):e48-e72. doi:10.1043/1543-2165-134.7.e48

22. Wolff AC, Hammond ME, Schwartz JN, Hagerty KL, Allred DC, Cote RJ, Dowsett M, Fitzgibbons PL, Hanna WM, Langer A, McShane LM, Paik S, Pegram MD, Perez EA, Press MF, Rhodes A, Sturgeon C, Taube SE, Tubbs R, Vance GH, van de Vijver M, Wheeler TM, Hayes DF (2007) American Society of Clinical Oncology/College of American Pathologists guideline recommendations for human epidermal growth factor receptor 2 testing in breast cancer. Arch Pathol Lab Med 131(1):18-43. doi:10.1043/1543-2165(2007)131[18:Asocco]2.0.Co;2

23. Third Report of the National Cholesterol Education Program (NCEP) (2002) Expert Panel on Detection, Evaluation, and Treatment of High Blood Cholesterol in Adults (Adult Treatment Panel III) final report. Circulation 106(25):3143-3421

24. Alberti KG, Eckel RH, Grundy SM, Zimmet PZ, Cleeman JI, Donato KA, Fruchart JC, James WP, Loria CM, Smith SC Jr (2009) Harmonizing the metabolic syndrome: a joint interim statement of the International Diabetes Federation Task Force on Epidemiology and Prevention; National Heart, Lung, and Blood Institute. American Heart Association; World Heart Federation; International Atherosclerosis Society; and International Association for the Study of Obesity. Circulation 120(16):1640-1645. doi:10.1161/circulationaha.109.192644

25. Kitahara CM, Berrington de González A, Freedman ND, Huxley R, Mok Y, Jee SH, Samet JM (2011) Total cholesterol and cancer risk in a large prospective study in Korea. Journal of clinical oncology: official journal of the American Society of Clinical Oncology 29(12):1592-1598. doi:10.1200/jco.2010.31.5200

26. Martin LJ, Melnichouk O, Huszti E, Connelly PW, Greenberg CV, Minkin S, Boyd NF (2015) Serum lipids, lipoproteins, and risk of breast cancer: a nested case-control study using multiple time points. 
J Natl Cancer Inst 107 (5). doi:10.1093/jnci/djv032

27. His M, Zelek L, Deschasaux M, Pouchieu C, Kesse-Guyot E, Hercberg S, Galan P, Latino-Martel P, Blacher J, Touvier M (2014) Prospective associations between serum biomarkers of lipid metabolism and overall, breast and prostate cancer risk. Eur J Epidemiol 29(2):119-132. doi:10.1007/s10654014-9884-5

28. Chandler PD, Song Y, Lin J, Zhang S, Sesso HD, Mora S, Giovannucci EL, Rexrode KE, Moorthy MV, Li C, Ridker PM, Lee IM, Manson JE, Buring JE, Wang L (2016) Lipid biomarkers and long-term risk of cancer in the Women's Health Study. Am J Clin Nutr 103(6):1397-1407. doi:10.3945/ajcn.115.124321

29. Nowak C, Ärnlöv J (2018) A Mendelian randomization study of the effects of blood lipids on breast cancer risk. Nature communications 9(1):3957. doi:10.1038/s41467-018-06467-9

30. Beeghly-Fadiel A, Khankari NK, Delahanty RJ, Shu XO, Lu Y, Schmidt MK, Bolla MK, Michailidou K, Wang Q, Dennis J, Yannoukakos D, Dunning AM, Pharoah PDP, Chenevix-Trench G, Milne RL, Hunter DJ, Per H, Kraft P, Simard J, Easton DF, Zheng W (2019) A Mendelian randomization analysis of circulating lipid traits and breast cancer risk. Int J Epidemiol. doi:10.1093/ije/dyz242

31. His M, Dartois L, Fagherazzi G, Boutten A, Dupré T, Mesrine S, Boutron-Ruault MC, Clavel-Chapelon F, Dossus $L$ (2017) Associations between serum lipids and breast cancer incidence and survival in the E3N prospective cohort study. Cancer causes control: CCC 28(1):77-88. doi:10.1007/s10552-0160832-4

32. Melvin JC, Seth D, Holmberg L, Garmo H, Hammar N, Jungner I, Walldius G, Lambe M, Wigertz A, Van Hemelrijck M (2012) Lipid profiles and risk of breast and ovarian cancer in the Swedish AMORIS study. Cancer epidemiology, biomarkers \& prevention: a publication of the American Association for Cancer Research, cosponsored by the American Society of Preventive Oncology 21 (8):1381-1384. doi:10.1158/1055-9965.Epi-12-0188

33. Inoue M, Noda M, Kurahashi N, Iwasaki M, Sasazuki S, Iso H, Tsugane S (2009) Impact of metabolic factors on subsequent cancer risk: results from a large-scale population-based cohort study in Japan. European journal of cancer prevention: the official journal of the European Cancer Prevention Organisation (ECP) 18(3):240-247. doi:10.1097/CEJ.0b013e3283240460

34. Ray G, Husain SA (2001) Role of lipids, lipoproteins and vitamins in women with breast cancer. Clinical biochemistry 34(1):71-76. doi:10.1016/s0009-9120(00)00200-9

35. Agurs-Collins T, Kim KS, Dunston GM, Adams-Campbell LL (1998) Plasma lipid alterations in AfricanAmerican women with breast cancer. J Cancer Res Clin Oncol 124(3-4):186-190. doi:10.1007/s004320050153

36. Maiti B, Kundranda MN, Spiro TP, Daw HA (2010) The association of metabolic syndrome with triplenegative breast cancer. Breast cancer research treatment 121(2):479-483. doi:10.1007/s10549-0090591-y

37. PARLAK Ö, KOCAÖZ SJOTSBD (2019) Increased Lipids Levels and Breast Cancer. 4 (2):128-138 
38. Llaverias G, Danilo C, Mercier I, Daumer K, Capozza F, Williams TM, Sotgia F, Lisanti MP, Frank PG (2011) Role of cholesterol in the development and progression of breast cancer. Am J Pathol 178(1):402-412. doi:10.1016/j.ajpath.2010.11.005

39. Danilo C, Frank PG (2012) Cholesterol and breast cancer development. Curr Opin Pharmacol 12(6):677-682. doi:10.1016/j.coph.2012.07.009

40. Furberg AS, Jasienska G, Bjurstam N, Torjesen PA, Emaus A, Lipson SF, Ellison PT, Thune I (2005) Metabolic and hormonal profiles: HDL cholesterol as a plausible biomarker of breast cancer risk. The Norwegian EBBA Study. Cancer epidemiology, biomarkers \& prevention: a publication of the American Association for Cancer Research. cosponsored by the American Society of Preventive Oncology 14(1):33-40

41. Hankinson SE (2005) Endogenous hormones and risk of breast cancer in postmenopausal women. Breast Dis 24:3-15. doi:10.3233/bd-2006-24102

42. Fernandez ML, Murillo AG (2016) Postmenopausal Women Have Higher HDL and Decreased Incidence of Low HDL than Premenopausal Women with Metabolic Syndrome. Healthcare (Basel Switzerland) 4 (1). doi:10.3390/healthcare4010020

43. von Eckardstein A, Hersberger M, Rohrer $L$ (2005) Current understanding of the metabolism and biological actions of HDL. Current opinion in clinical nutrition and metabolic care 8 (2):147-152. doi:10.1097/00075197-200503000-00007

44. Soran H, Hama S, Yadav R, Durrington PN (2012) HDL functionality. Current opinion in lipidology 23 (4):353-366. doi:10.1097/MOL.0b013e328355ca25

45. Yvan-Charvet L, Wang N, Tall AR (2010) Role of HDL, ABCA1, and ABCG1 transporters in cholesterol efflux and immune responses. Arteriosclerosis, thrombosis, and vascular biology 30 (2):139-143. doi:10.1161/atvbaha.108.179283

46. Pan B, Ren H, He Y, Lv X, Ma Y, Li J, Huang L, Yu B, Kong J, Niu C, Zhang Y, Sun WB, Zheng L (2012) $\mathrm{HDL}$ of patients with type 2 diabetes mellitus elevates the capability of promoting breast cancer metastasis. Clinical cancer research: an official journal of the American Association for Cancer Research 18(5):1246-1256. doi:10.1158/1078-0432.Ccr-11-0817

47. Pan B, Ren H, Lv X, Zhao Y, Yu B, He Y, Ma Y, Niu C, Kong J, Yu F, Sun WB, Zhang Y, Willard B, Zheng L (2012) Hypochlorite-induced oxidative stress elevates the capability of HDL in promoting breast cancer metastasis. Journal of translational medicine 10:65. doi:10.1186/1479-5876-10-65

48. Pan B, Ren H, Ma Y, Liu D, Yu B, Ji L, Pan L, Li J, Yang L, Lv X, Shen X, Chen B, Zhang Y, Willard B, He $Y$, Zheng $L$ (2012) High-density lipoprotein of patients with type 2 diabetes mellitus elevates the capability of promoting migration and invasion of breast cancer cells. International journal of cancer 131(1):70-82. doi:10.1002/ijc.26341

49. Newman LA, Kaljee LM (2017) Health Disparities and Triple-Negative Breast Cancer in African American Women: A Review. JAMA surgery 152(5):485-493. doi:10.1001/jamasurg.2017.0005

50. Garrido-Castro AC, Lin NU, Polyak K (2019) Insights into Molecular Classifications of Triple-Negative Breast Cancer: Improving Patient Selection for Treatment. Cancer discovery 9(2):176-198. 
doi:10.1158/2159-8290.Cd-18-1177

51. Jiagge E, Jibril AS, Chitale D, Bensenhaver JM, Awuah B, Hoenerhoff M, Adjei E, Bekele M, Abebe E, Nathanson SD, Gyan K, Salem B, Oppong J, Aitpillah F, Kyei I, Bonsu EO, Proctor E, Merajver SD, Wicha M, Stark A, Newman LA (2016) Comparative Analysis of Breast Cancer Phenotypes in African American, White American, and West Versus East African patients: Correlation Between African Ancestry and Triple-Negative Breast Cancer. Ann Surg Oncol 23(12):3843-3849. doi:10.1245/s10434-016-5420-z

52. Newman LA (2015) Disparities in breast cancer and african ancestry: a global perspective. The breast journal 21(2):133-139. doi:10.1111/tbj.12369

\section{Tables}


Table 1

Clinical and reproductive characteristics of MEND breast cancer cases and controls

\begin{tabular}{|c|c|c|c|}
\hline Variable & $\begin{array}{l}\text { Case } \\
N=296\end{array}$ & $\begin{array}{l}\text { Controls } \\
N=116\end{array}$ & P-value \\
\hline \multicolumn{4}{|l|}{ Demographics } \\
\hline Age $\left(\right.$ years) ${ }^{\mathrm{a}}$ & $48.5(42.0,57.0)$ & $46.0(40.0,54.5)$ & 0.0328 \\
\hline \multicolumn{4}{|l|}{ Clinical characteristics } \\
\hline \multicolumn{4}{|l|}{ Lipid Profile ${ }^{a}$} \\
\hline Total cholesterol (mg/dL) & $169.0(142.5,199.5)$ & $162.0(131.0,190.0)$ & 0.0384 \\
\hline HDL-cholesterol (mg/dL) & $49.6(39.2,59.2)$ & $47.4(35.7,55.7)$ & 0.0683 \\
\hline LDL-cholesterol (mg/dL) & $83.1(66.6,104.6)$ & $76.2(58.8,97.5)$ & 0.0376 \\
\hline Triglycerides (mg/dL) & $87.0(60.0,125.0)$ & $74.0(57.0,104.0)$ & 0.0478 \\
\hline Total cholesterol (mg/dL) & & & 0.3927 \\
\hline High (> 200) & $73(24.7)$ & $24(20.7)$ & \\
\hline $\operatorname{Low}(\leq 200)$ & $223(75.3)$ & $92(79.3)$ & \\
\hline HDL-cholesterol (mg/dL) & & & 0.3587 \\
\hline Low $(<50)$ & $151(51.0)$ & $65(56.0)$ & \\
\hline High $(\geq 50)$ & $145(49.0)$ & $51(44.0)$ & \\
\hline LDL-cholesterol (mg/dL) & & & 0.1680 \\
\hline High $(>100)$ & $89(30.1)$ & $27(23.3)$ & \\
\hline $\operatorname{Low}(\leq 100)$ & $207(69.9)$ & $89(76.7)$ & \\
\hline Triglycerides (mg/dL) & & & 0.1493 \\
\hline High (> 150) & $47(15.9)$ & $12(10.3)$ & \\
\hline Low $(\leq 150)$ & $249(84.1)$ & $104(89.7)$ & \\
\hline Height (in) ${ }^{a}$ & $63.1(61.4,64.8)$ & $63.0(61.0,65.4)$ & 0.9311 \\
\hline Weight $(\mathrm{lb})^{\mathrm{a}}$ & $143.0(121.0,165.2)$ & $152.7(127.9,176.4)$ & 0.0227 \\
\hline Systolic BPa & $125.0(114.7,140.5)$ & $122.7(109.2,135.5)$ & 0.0687 \\
\hline Diastolic $\mathrm{BP}^{\mathrm{a}}$ & $79.7(70.7,88.7)$ & $75.0(68.0,82.8)$ & 0.0056 \\
\hline
\end{tabular}




\begin{tabular}{|llll|}
\hline Variable & $\begin{array}{l}\text { Case } \\
\mathbf{N}=296\end{array}$ & $\begin{array}{l}\text { Controls } \\
\mathbf{N}=116\end{array}$ & P-value \\
\hline Body Mass Index (BMI) & $25.4(22.2,29.6)$ & $26.5(23.1,31.4)$ & 0.0451 \\
\hline Hypertension at enrollment & $87(29.4)$ & $25(21.6)$ & 0.1077 \\
\hline Reproductive history & & & \\
\hline Age at menarche & & & 0.8851 \\
\hline$\leq 13$ & $60(20.3)$ & $76(16.4)$ & \\
\hline$>13$ & $230(77.7)$ & $21(18.1)$ & 0.8508 \\
\hline Missing & $6(2.0)$ & $110(94.8)$ & 0.7457 \\
\hline Ever pregnant & $282(95.3)$ & $5.0(3.0,6.0)$ & 0.8457 \\
\hline Number of pregnancies ${ }^{\text {a,b }}$ & $5.0(3.0,6.0)$ & $4.0(2.0,5.0)$ & \\
\hline Number of births ${ }^{\text {a.b }}$ & $4.0(3.0,5.0)$ & & \\
\hline Menopausal status & & & \\
\hline Pre- or peri-menopause & $143(48.3)$ & $59(49.1)$ & \\
\hline Post-menopause & $153(51.7)$ & N/Ac & \\
\hline Cancer type & $\mathrm{N}=124$ & & \\
\hline Luminal A & $33(26.6)$ & & \\
\hline Luminal B & $26(21.0)$ & & \\
\hline Triple-negative & $37(29.8)$ & & \\
\hline HER2+ & $28(22.6)$ & & \\
\hline a Median (Q1, Q3). & & & \\
bAmong those who were ever pregnant. & & \\
\hline $\begin{array}{l}\text { CCancer variables are not applicable to control participants. } \\
\text { Where applicable, missing values were not used to compute p-value. }\end{array}$ & \\
\hline
\end{tabular}

Table 2. Clinical and reproductive characteristics of MEND cases and controls by quartile of total cholesterol 


\section{Quartile of Total Cholesterol (mg/dL)}

\begin{tabular}{|c|c|c|c|c|c|}
\hline Variable & $\begin{array}{l}\mathrm{Q} 1 \\
\leq 140.00 \\
\mathrm{mg} / \mathrm{dL} \\
\mathrm{N}=104\end{array}$ & $\begin{array}{l}\text { Q2 } \\
>140.00- \\
\leq 167.00 \mathrm{mg} / \mathrm{dL} \\
\mathrm{N}=105\end{array}$ & $\begin{array}{l}\text { Q3 } \\
>167.00- \\
\leq 198.00 \mathrm{mg} / \mathrm{dL} \\
\mathrm{N}=102\end{array}$ & $\begin{array}{l}\mathrm{Q} 4 \\
>198.00 \\
\mathrm{mg} / \mathrm{dL} \\
\mathrm{N}=101\end{array}$ & $\begin{array}{l}\mathrm{P}- \\
\text { value }\end{array}$ \\
\hline Case status & & & & & 0.1291 \\
\hline Case & $66(22.3)$ & $75(25.3)$ & $78(26.4)$ & $77(26.0)$ & \\
\hline Control & $38(32.8)$ & $30(25.9)$ & $24(20.7)$ & $24(20.7)$ & \\
\hline \multicolumn{6}{|l|}{ Demographics } \\
\hline Age (years) ${ }^{a}$ & $\begin{array}{l}44.0(38.5, \\
52.0)\end{array}$ & $46.0(41.0,55.0)$ & $49.0(42.0,59.0)$ & $\begin{array}{l}52.0(47.0, \\
59.0)\end{array}$ & 0.0003 \\
\hline \multicolumn{6}{|l|}{$\begin{array}{l}\text { Clinical } \\
\text { characteristics }\end{array}$} \\
\hline Height (in) ${ }^{a}$ & $\begin{array}{l}63.0(61.1, \\
64.9)\end{array}$ & $63.4(62.2,65.0)$ & $63.0(60.8,64.6)$ & $\begin{array}{l}63.1(61.6 \\
65.5)\end{array}$ & 0.3569 \\
\hline Weight $(\mathrm{lb})^{\mathrm{a}}$ & $\begin{array}{l}\text { 137.7 (121.1, } \\
160.7)\end{array}$ & $\begin{array}{l}143.3(120.8 \\
172.0)\end{array}$ & $\begin{array}{l}143.3(125.5 \\
174.4)\end{array}$ & $\begin{array}{l}152.1 \\
(130.1 \\
176.4)\end{array}$ & 0.0593 \\
\hline Systolic BPa & $\begin{array}{l}124.3(111.0 \\
138.8)\end{array}$ & $\begin{array}{l}\text { 119.7 (110.0, } \\
134.0)\end{array}$ & $\begin{array}{l}125.3(115.7 \\
144.7)\end{array}$ & $\begin{array}{l}130.3 \\
(120.0 \\
145.0)\end{array}$ & 0.0067 \\
\hline Diastolic BPa & $\begin{array}{l}76.5(69.7 \\
87.3)\end{array}$ & $75.0(68.7,82.3)$ & $80.0(70.7,89.7)$ & $\begin{array}{l}80.0(71.0 \\
90.0)\end{array}$ & 0.0202 \\
\hline $\begin{array}{l}\text { Body Mass Index } \\
(\text { BMI })^{a}\end{array}$ & $\begin{array}{l}24.6(20.9 \\
28.7)\end{array}$ & $25.4(21.8,29.7)$ & $25.9(23.3,30.3)$ & $\begin{array}{l}26.2(23.1 \\
31.5)\end{array}$ & 0.0396 \\
\hline $\begin{array}{l}\text { Hypertension at } \\
\text { enrollment }\end{array}$ & $26(23.2)$ & $20(17.9)$ & $29(25.9)$ & $37(33.0)$ & 0.0385 \\
\hline \multicolumn{6}{|l|}{$\begin{array}{l}\text { Reproductive } \\
\text { history }\end{array}$} \\
\hline Age at menarche & & & & & 0.0222 \\
\hline$\leq 13$ & $30(38.0)$ & 15 (19.0) & $17(21.5)$ & $17(21.5)$ & \\
\hline$>13$ & $65(21.2)$ & $81(26.5)$ & $79(25.8)$ & $81(26.5)$ & \\
\hline Missing & 9 (33.3) & $9(33.3)$ & $6(22.2)$ & $3(11.1)$ & \\
\hline Ever pregnant & $97(24.7)$ & $101(25.8)$ & $96(24.5)$ & $98(25.0)$ & 0.5878 \\
\hline $\begin{array}{l}\text { Number of } \\
\text { pregnancies }\end{array}$ & $4.0(4.0,6.0)$ & $5.0(3.0,7.0)$ & $5.0(3.0,6.0)$ & $5.0(3.0,6.0)$ & 0.9480 \\
\hline
\end{tabular}




\begin{tabular}{|c|c|c|c|c|c|}
\hline \multirow[b]{2}{*}{$\begin{array}{l}\text { Number of } \\
\text { births } s^{\text {a.b }}\end{array}$} & \multicolumn{5}{|c|}{ Quartile of Total Cholesterol (mg/dL) } \\
\hline & $4.0(3.0,5.0)$ & $4.0(3.0,5.0)$ & $4.0(2.0,5.0)$ & $4.0(2.0,5.0)$ & 0.8751 \\
\hline $\begin{array}{l}\text { Menopausal } \\
\text { status }\end{array}$ & & & & & 0.0003 \\
\hline $\begin{array}{l}\text { Pre- or peri- } \\
\text { menopause }\end{array}$ & $67(33.5)$ & $53(26.5)$ & $44(22.0)$ & $36(18.0)$ & \\
\hline Post-menopause & $37(17.5)$ & $52(24.5)$ & $58(27.4)$ & $65(30.7)$ & \\
\hline \multicolumn{2}{|l|}{ a Median (Q1, Q3). } & t. & te p-value. & & \\
\hline
\end{tabular}


Table 4

Associations between lipid biomarkers and breast cancer subtype

\begin{tabular}{|c|c|c|c|c|}
\hline & Luminal A & Luminal B & $\begin{array}{l}\text { Triple } \\
\text { Negative }\end{array}$ & HER2 \\
\hline & aOR $(95 \% \mathrm{Cl})$ & aOR $(95 \% \mathrm{Cl})$ & aOR $(95 \% \mathrm{Cl})$ & aOR $(95 \% \mathrm{Cl})$ \\
\hline \multicolumn{5}{|l|}{$\begin{array}{l}\text { Total Cholesterol } \\
(\mathrm{mg} / \mathrm{dL})\end{array}$} \\
\hline High vs. Low & $\begin{array}{l}0.63(0.20 \\
1.98)\end{array}$ & $\begin{array}{l}1.38 \\
3.92)\end{array}$ & $\begin{array}{l}0.92(0.35 \\
2.41)\end{array}$ & $1.17(0.41,3.31)$ \\
\hline $\begin{array}{l}\text { per one-unit SD } \\
\text { increase }\end{array}$ & $\begin{array}{l}0.99(0.64 \\
1.55)\end{array}$ & $\begin{array}{l}1.34(0.92, \\
1.96)\end{array}$ & $\begin{array}{l}0.98(0.63 \\
1.51)\end{array}$ & $1.01(0.65,1.57)$ \\
\hline \multicolumn{5}{|l|}{$\begin{array}{l}\text { HDL Cholesterol } \\
(\mathrm{mg} / \mathrm{dL})\end{array}$} \\
\hline Low vs. High & $\begin{array}{l}0.92(0.38 \\
2.22)\end{array}$ & $\begin{array}{l}1.11(0.44 \\
2.78)\end{array}$ & $\begin{array}{l}2.67(1.10 \\
6.49)\end{array}$ & $0.91(0.37,2.26)$ \\
\hline $\begin{array}{l}\text { per one-unit SD } \\
\text { decrease }\end{array}$ & $\begin{array}{l}0.96(0.64 \\
1.44)\end{array}$ & $\begin{array}{l}0.84(0.53 \\
1.32)\end{array}$ & $\begin{array}{l}1.49(0.94 \\
2.34)\end{array}$ & $0.93(0.60,1.45)$ \\
\hline \multicolumn{5}{|l|}{$\begin{array}{l}\text { LDL Cholesterol } \\
(\mathrm{mg} / \mathrm{dL})\end{array}$} \\
\hline High vs. Low & $\begin{array}{l}1.96(0.71, \\
5.40)\end{array}$ & $\begin{array}{l}2.56(0.92 \\
7.11)\end{array}$ & $\begin{array}{l}2.10(0.87 \\
5.11)\end{array}$ & $1.72(0.61,4.80)$ \\
\hline $\begin{array}{l}\text { per one-unit SD } \\
\text { increase }\end{array}$ & $\begin{array}{l}1.21(0.75 \\
1.98)\end{array}$ & $\begin{array}{l}1.64(1.06 \\
2.55)\end{array}$ & $\begin{array}{l}1.34(0.88 \\
2.06)\end{array}$ & $1.02(0.60,1.72)$ \\
\hline \multicolumn{5}{|c|}{ Triglycerides (mg/dL) } \\
\hline High vs. Low & $\begin{array}{l}1.03(0.25 \\
4.34)\end{array}$ & $\begin{array}{l}1.12(0.28 \\
4.58)\end{array}$ & $\begin{array}{l}1.57(0.51 \\
4.85)\end{array}$ & $2.64(0.81,8.59)$ \\
\hline $\begin{array}{l}\text { per one-unit SD } \\
\text { increase }\end{array}$ & $\begin{array}{l}1.32(0.81 \\
2.15)\end{array}$ & $\begin{array}{l}1.53(0.97 \\
2.42)\end{array}$ & $1.38(0.90,2.11)$ & $\begin{array}{l}1.36(0.85 \\
2.18)\end{array}$ \\
\hline \multicolumn{5}{|c|}{$\begin{array}{l}\text { Multinomial logistic regression models predicted odds of having each cancer subtype, compared to } \\
\text { no cancer, using lipid profile biomarkers. ORs per one-unit SD were modeled as a one-unit } \\
\text { increase/decrease in standard deviation of the lipid profile variable from its mean-centered value. } \\
\text { Bolded values indicate significance at } \mathrm{p}<.05 \text {. } \\
\text { High total cholesterol defined as }>200 \mathrm{mg} / \mathrm{dL} \text {; low } \mathrm{HDL} \text { defined as }<50 \mathrm{mg} / \mathrm{dL} \text {; high } \mathrm{LDL} \text { defined as }> \\
100 \mathrm{mg} / \mathrm{dL} \text {; high triglycerides defined as }>150 \mathrm{mg} / \mathrm{dL} \text {. } \\
\text { Models were adjusted for age and clinical characteristics: BMl, age at menarche, number of } \\
\text { pregnancies, number of births, hypertension at enrollment, and menopausal status. } \\
\text { Abbreviations: aOR, adjusted odds ratio; } \mathrm{Cl} \text {, confidence interval; } S D \text {, standard deviation. }\end{array}$} \\
\hline
\end{tabular}

\section{Figures}




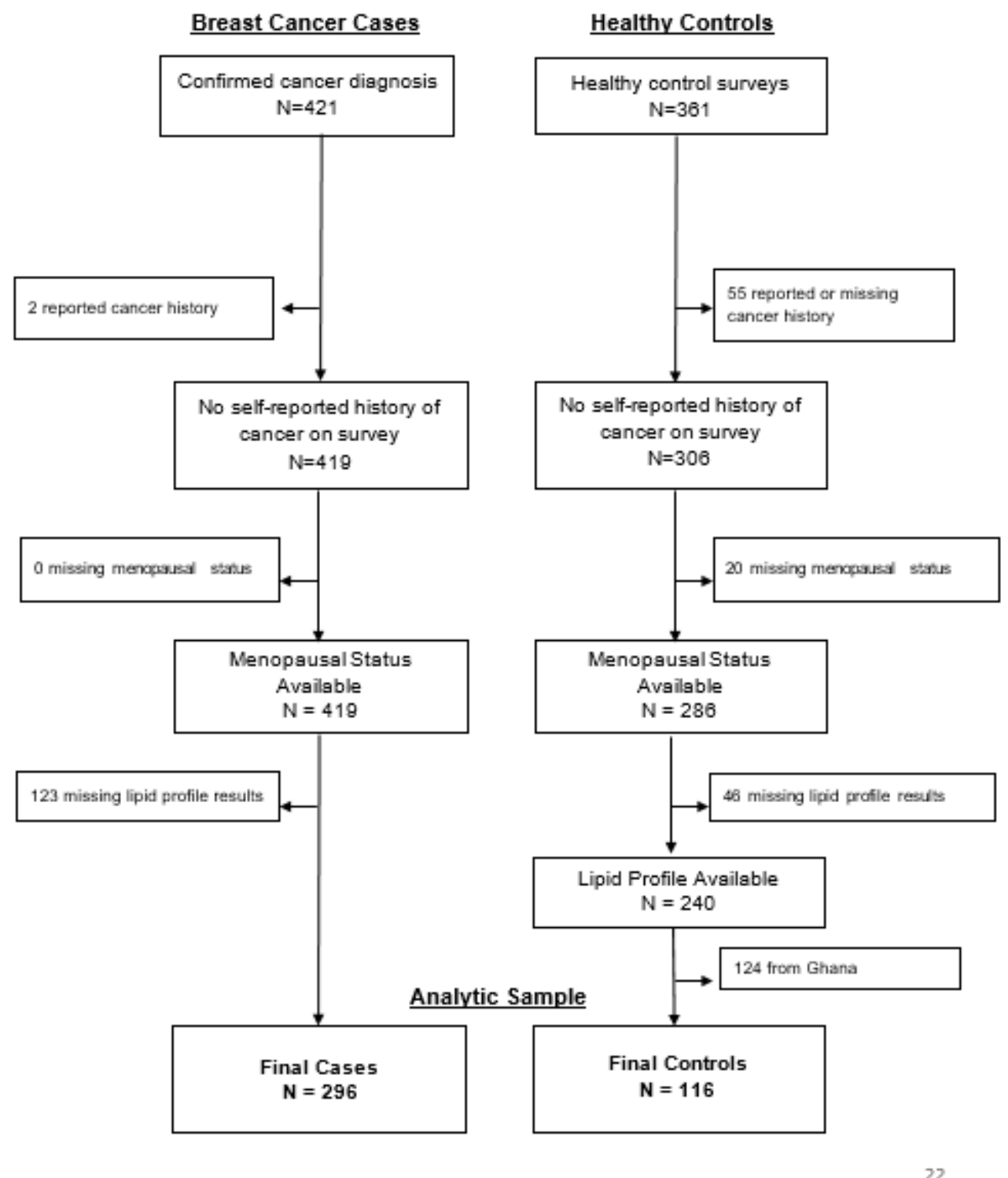

Figure 1

CONSORT diagram for MEND lipid profile analysis 

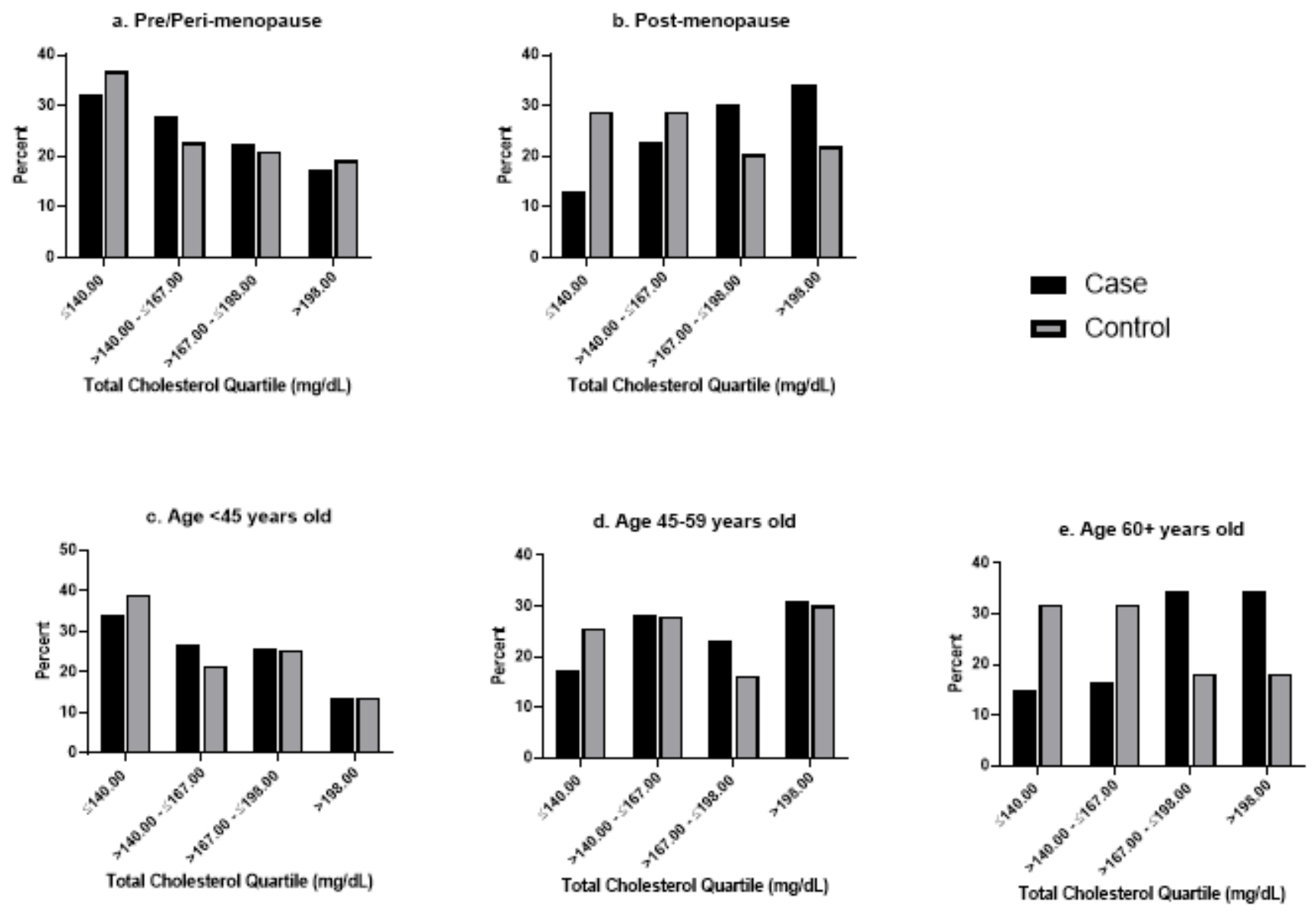

Figure 2

Total cholesterol quartile by case/control status and clinical factors 


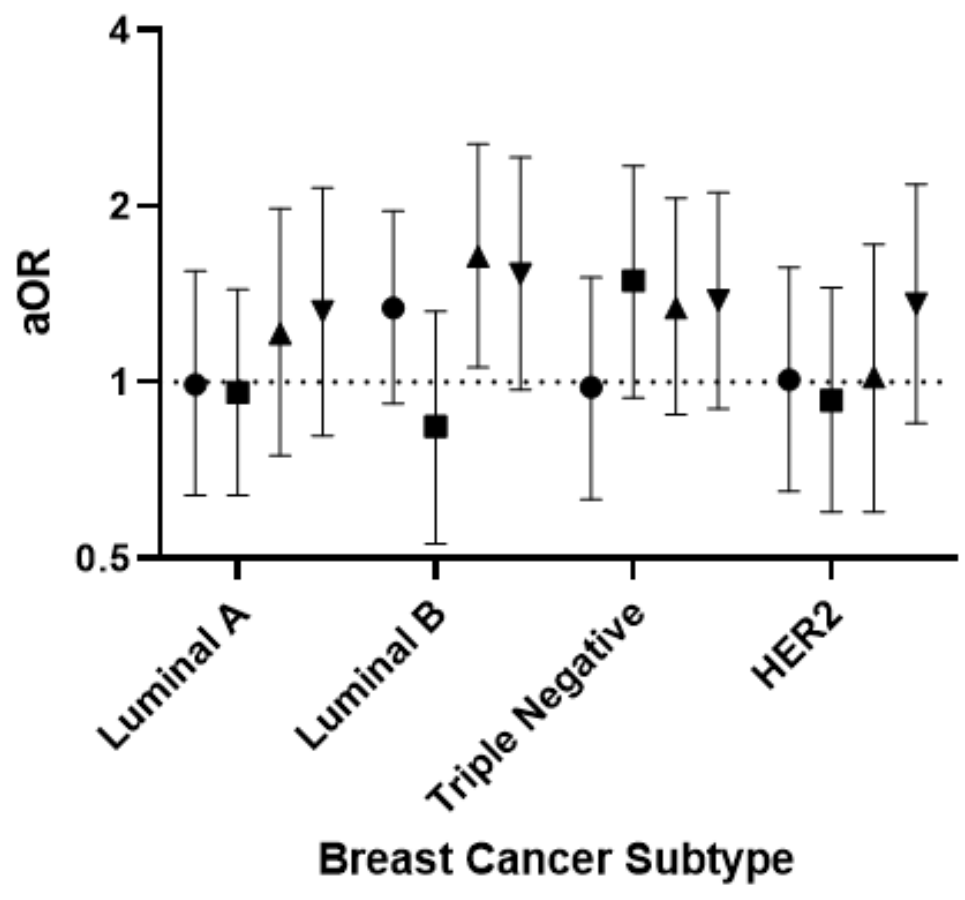

- Total Cholesterol per unit SD increase

- HDL per unit SD decrease

- LDL per unit SD increase

V Triglycerides per unit SD increase

\section{Figure 3}

Associations between lipid biomarkers and breast cancer subtypes (reference group = control; adjusted for age, $\mathrm{BMI}$, age at menarche, number of pregnancies, number of births, hypertension at enrollment, and menopausal status) 